\title{
Nieleczone zniekształcenia narządu ruchu w przebiegu chorób systemowych - analiza przypadku
}

\section{Untreated deformities of motor system in systemic diseases - a case study}

\author{
Jacek Lorkowski1, 2, Oliwia Grzegorowska², Ireneusz Kotela \\ ${ }^{1}$ Klinika Ortopedii i Traumatologii Centralnego Szpitala Klinicznego MSW w Warszawie \\ ul. Wołoska 137, 02-507 Warszawa \\ Kierownik: prof. nadzw. dr hab. n. med. Ireneusz Kotela
}

${ }^{2}$ Centrum Rehabilitacji „Zdrowie”

ul. Św. Gertrudy 28, 31-048 Kraków

Kierownik: dr n. med. Tadeusz Mazur

\section{SUMMARY}

The synergy of two arthritides coexistence is very rare. In this paper we describe a 46-year-old patient with psoriatic and gouty arthritis. The pathologies had been developing for a dozen or so years in the ulnar area of both upper limbs. The patient elected to undergo surgical treatment in a very advanced stage of the disease due to increasing psychological discomfort.

Key words: gout, psoriatic arthritis, tophi, quality of life.

\section{STRESZCZENIE}

Synergizm występowania łuszczycowego zapalenia stawów oraz zapalenia stawów w przebiegu dny moczanowej jest rzadkim zjawiskiem. W pracy przedstawiono przypadek 46-letniego pacjenta u którego zdiagnozowano obydwie jednostki chorobowe. U chorego w ciągu kilkunastu lat rozwinęły się kilkucentymetrowe guzki dnawe w okolicach łokciowych obu kończyn górnych. Pacjent zgłosił się celem leczenia w bardzo zaawansowanym stadium choroby z powodu narastającego dyskomfortu psychicznego.

Słowa kluczowe: dna moczanowa, łuszczycowe zapalenie stawów, guzki dnawe, jakość życia.

\section{WSTĘP}

Synergizm występowania łuszczycowego zapalenia stawów (ŁZS) i dny moczanowej nie jest powszechny, stwierdza się jednak zwiększone ryzyko zachorowania na dnę moczanową u chorych z łuszczycą [1]. Widoczne zewnętrznie znacznego stopnia zniekształcenia w obrębie narządu ruchu, występujące w przebiegu każdego z tych schorzeń, są najczęściej powodem szybkiego zgłaszania się chorych do lekarza.

Przedstawiono przypadek pacjenta, u którego zdiagnozowano zarówno dnę moczanową, jak i ŁZS. Pomimo znacznego stopnia zniekształceń okolicy łokciowej w obu kończynach górnych, spowodowanych guzkami dnawymi, chory przez kilka lat nie decydował się na leczenie operacyjne.

\section{OPIS PRZYPADKU}

Pacjent T.M., lat 46, zgłosił się celem operacyjnego usunięcia obustronnych olbrzymich $(7 \times 7 \mathrm{~cm})$ guzków dnawych w obrębie powierzchni grzbietowej końca bliższego obu kości łokciowych (ryc. 1), powodujących jego zdaniem dyskomfort psychiczny, który zmniejszał jakość życia. Guzki od kilkunastu lat stopniowo się powiększały. Pacjent dotychczas w pełni akceptował obraz makroskopowy stwierdzany w obrębie kończyn górnych i nie zdecydował się wcześniej na leczenie operacyjne, mimo iż jest osobą publiczną.

U chorego przed kilku laty zdiagnozowano ŁZS oraz dnę moczanową, jednak nie leczył się on w sposób regularny, pomimo zaleconej farmakoterapii (m.in. allopurinol, miejscowe leczenie zmian łuszczycowych, suplementacja siarczanu chondroityny). Dolegliwości bólowe w subiektywnej ocenie pacjenta nie zmniejszały w sposób znaczny jakości życia (okresowo dolegliwości 1-2/10 wg wizualnej skali analogowej). Fizykalnie w zakresie stawów łokciowych zauważono symetryczny
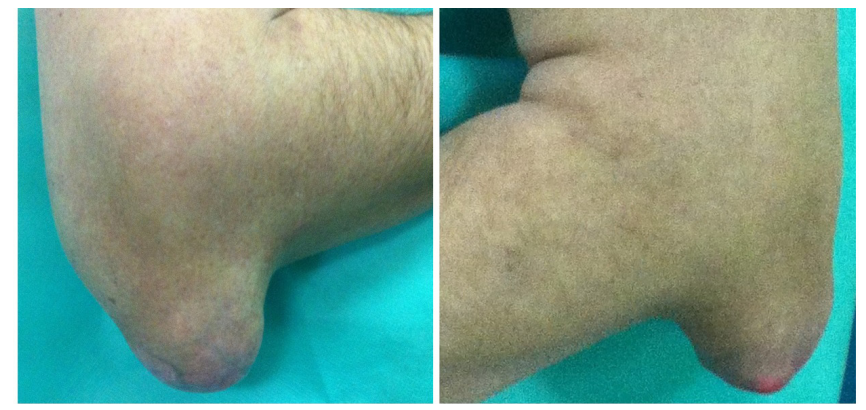

RYCINA 1. Olbrzymie guzki dnawe w obrębie powierzchni grzbietowej końca bliższego obu kości łokciowych 
deficyt wyprostu o $15^{\circ}$ oraz ograniczenie nawracania o $20^{\circ}$. Pozostałe ruchy w stawach łokciowych były możliwe w pełnym zakresie i niebolesne. Z odchyleń od normy odnotowano również niewielkiego stopnia niestabilność stawów w płaszczyźnie czołowej.
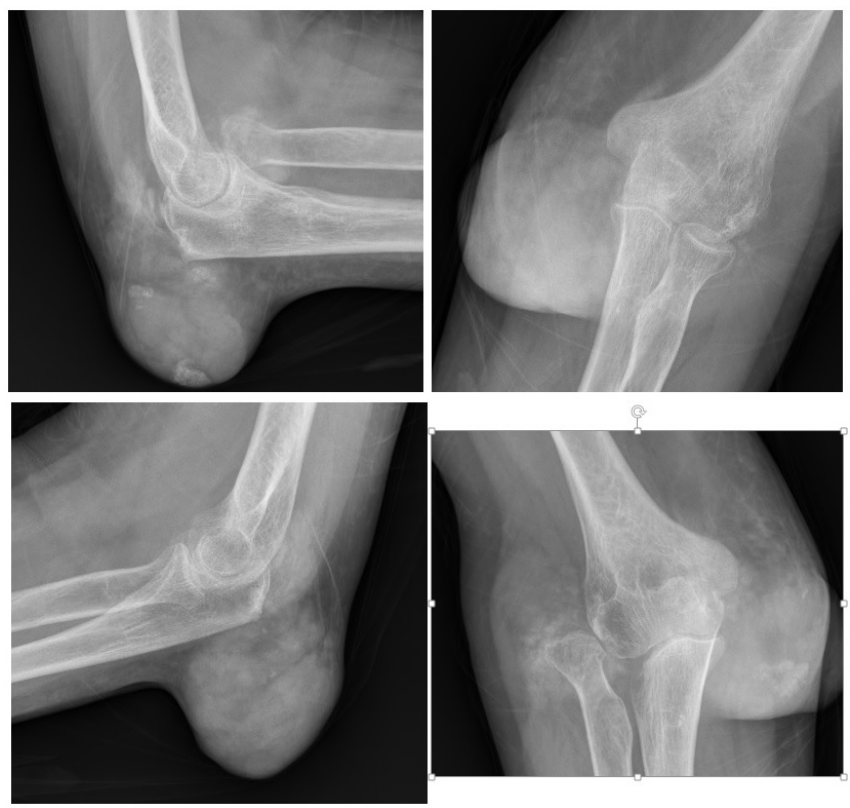

RYCINA 2. Radiogramy obu stawów łokciowych w projekcji bocznej i przednio-tylnej z widocznymi olbrzymimi guzkami dnawymi po stronie tylnej końców bliższych obu przedramion; dodatkowo widoczne obustronne podwichnięcia w stawach ramienno-promieniowych i promieniowo-łokciowych oraz zmiany zwyrodnieniowe

W przedoperacyjnym badaniu radiologicznym stwierdzono, poza masywnymi widocznymi w badaniu fizykalnym guzkami dnawymi i nieznacznego stopnia zmianami zwyrodnieniowymi, obustronne podwichnięcia w stawach ramienno-promieniowych i promieniowo-łokciowych oraz średnio zaawansowane zmiany zwyrodnieniowe (ryc. 2). W stawach kolanowych ruchy wykonywane były w pełnym zakresie, okresowo bolesne. W zakresie innych stawów nie odnotowano istotnych patologii.

W badaniach laboratoryjnych stwierdzono: niedokrwistość mikrocytarną (najprawdopodobniej w przebiegu chorób przewlekłych), nieznaczną hiponatremię, hiperurykemię, wzrost aminotransferazy asparaginianowej, gamma-glutamylotranspeptydazy, fosfatazy alkalicznej i odczynu Biernackiego, nieznacznie obniżony czas kaolinowo-kefalinowy, w rozdziale elektroforetycznym białek w surowicy krwi wzrost odsetka gamma-globulin przy prawidłowej wartości białka całkowitego w surowicy oraz zwiększone wydalanie białka w badaniu ogólnym moczu.

W dniu 28.02.2014 r. u pacjenta wykonano zabieg resekcji guzków dnawych (ryc. 3 i 4). Na korekcję ustawienia głów kości promieniowych i bardziej rozległą plastykę tkanek miękkich chory nie wyraził zgody. Wynik badania histopatologicznego potwierdził obraz kliniczny - guzki dnawe. Uzyskano poprawne wygojenie ran. Po zabiegu stwierdzono poprawę zakresu ruchomości w stawach łokciowych (obustronny deficyt
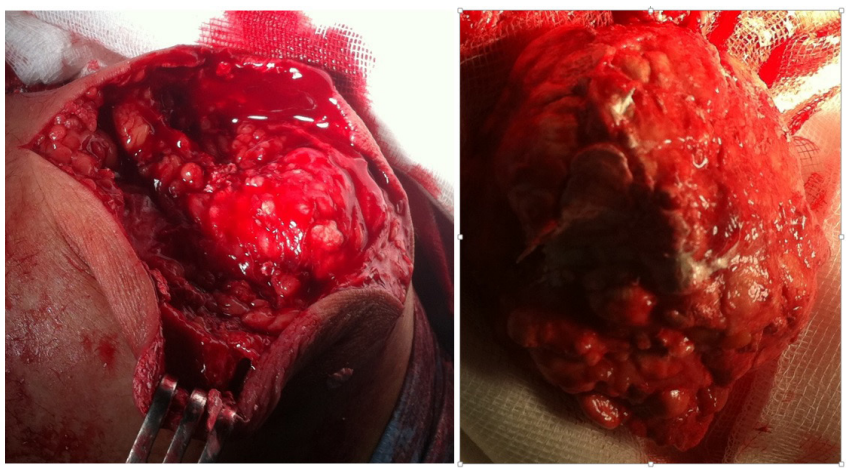

RYCINA 3. Obraz śródoperacyjny resekcji olbrzymich guzków dnawych

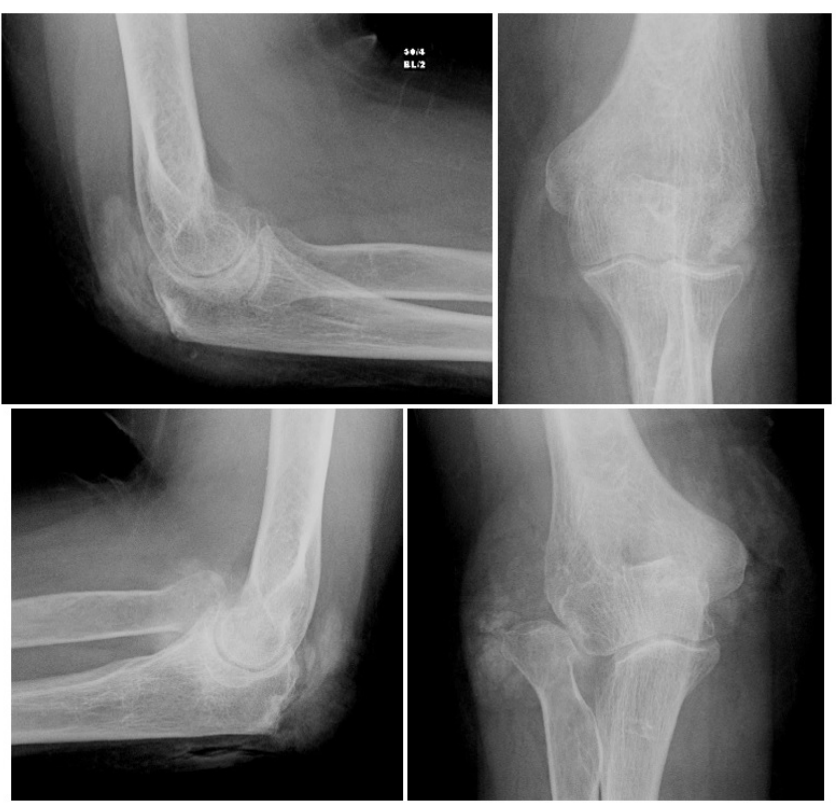

RYCINA 4. Radiogramy obu stawów łokciowych w projekcji bocznej i przednio-tylnej po zabiegu resekcji olbrzymich guzków dnawych występujących po stronie tylnej końców bliższych obu przedramion

wyprostu: $5^{\circ}$ ). Wyniki w skali Mayo Elbow Performance Score wynosiły odpowiednio: przed zabiegiem 65 pkt, a 3 miesiące po zabiegu 80 pkt.

\section{DYSKUSJA}

Najczęściej występującym zapaleniem stawów wśród chorób systemowych jest reumatoidalne zapalenie stawów (RZS). Niewiele natomiast jest udokumentowanych przypadków nakładania się na siebie różnych rodzajów zapaleń stawów [2]. Wśród opublikowanych artykułów tylko nieliczne prace opisują pacjentów z dwoma reumatycznymi jednostkami chorobowymi pierwotnie dotykającymi stawów - zazwyczaj opisywane są przypadki współistnienia RZS oraz zapalenia stawów w przebiegu dny moczanowej. Do tej pory ukazał się jeden opis przypadku pacjenta z trzema różnymi zapaleniami stawów: RZS, ŁZS oraz zapaleniem stawów w przebiegu dny moczanowej [3] (dane z wyszukiwarki PubMed na dzień 8.12.2014 r.). 
Warto również wspomnieć, iż często objawy dny moczanowej pokrywają się z tymi w przebiegu RZS lub ŁZS. Jednostki te bywają więc trudne do rozróżnienia i diagnostyki, a tym samym rzadko myśli się o ich nakładaniu [4]. Z tego względu przedstawiony przypadek jest ciekawy.

Łuszczycowe zapalenie stawów dotyka ok. 10\% chorych na łuszczycę i jest jedną z najcięższych postaci zapalenia stawów. W przypadku dny moczanowej odnotowuje się natomiast wzrost zapadalności [2]. U pacjentów chorych na łuszczycę stwierdza się zwiększone ryzyko wystąpienia dny moczanowej wynikające z podwyższonych wartości kwasu moczowego w surowicy krwi - zwiększenie jego syntezy związane jest bowiem z szybkim obrotem komórek naskórka, który skutkuje zwiększoną syntezą puryn w organizmie [5]. Ten proces sprzyja powstawaniu i odkładaniu się kryształów kwasu moczowego w stawach, które z kolei wy wołują odpowiedź zapalną obejmującą również struktury okołostawowe [6].

Istotny jest problem standardowo nie poruszany w ortopedii, tj. późny czas zgłaszania się do leczenia pacjentów z widocznymi makroskopowo zaawansowanymi już zmianami. Problem zmian w przebiegu chorób nowotworowych przekracza ramy tej pracy. Pytanie rodzi się jednak również w przypadku tak dużych widocznych zmian w przebiegu chorób nienowotworowych. Wpływają one na obraz fizyczny pacjenta i mogą powodować dyskomfort psychiczny oraz różnego rodzaju dolegliwości. W psychiatrii operuje się pojęciem „dysmorfofobia”, które oznacza poczucie istnienia fizycznego defektu oraz brzydoty, którą według chorego zauważają też inne osoby, oraz związanego z tym silnego dyskomfortu psychicznego. W omawianym przypadku zaistniała odwrotna sytuacja - pacjent nie zauważał defektu fizycznego, być może nawet negował jego istnienie i dopiero w po wielu latach zgłosił się do lekarza. W nazewnictwie medycznym nie istnieje pojęcie „adysmorfofobia”, które wydawałby się, per analogiam, odpowiednim określeniem w takiej sytuacji. Nie jest to pierwszy taki przypadek - istnienie olbrzymich guzków dnawych oraz późne zgłoszenie się pacjentów do lekarza niejednokrotnie zostało opisane w piśmiennictwie $[7,8]$. Choroby przewlekłe, jak również choroby narządu ruchu, mają wpływ na powstawanie zaburzeń afektywnych, w tym choroby afektywnej dwubiegunowej, oraz pogorszenie jakości życia $[9,10]$.

W pracy przedstawiono trudny przypadek, który jest zagadnieniem interdyscyplinarnym, dotyczącym psychiatrii i innych dziedzin medycyny, dlatego wymaga bardziej wnikliwych badań.

\section{PIŚMIENNICTWO}

1. Merola J.F., Wu S., Han J., Choi H.K., Qureshi A.A.: Psoriasis, psoriatic arthritis and risk of gout in US men and women. Ann Rheum Dis. 2015, 74 (8), 1495-1500.

2. Gabriel S.E., Michaud K.: Epidemiological studies in incidence, prevalence, mortality, and comorbidity of the rheumatic diseases. Arthritis Res Ther. 2009, 11 (3), 229-245.

3. Henriques C.C., Lourenço F., Lopéz B., Panarra A., Riso N.: Multiple arthritis: three in one. BMJ Case Rep. 2012, 8-11.

4. Tausche A.K., Manger B., Müller-Ladner U., Schmidt B.: Gout as a systemic disease. Manifestations, complications and comorbidities of hyperuricaemia. Z Rheumatol. 2012, 71 (3), 224-230.

5. Khondker L., Khan S.I.: Association of rheumatoid factor and uric acid with psoriatic arthritis: a review. Mymensingh Med J. 2014, 23 (3), 609-613.

6. Montero-Melendez T., Patel H.B., Perretti M.: Role of melanocortin receptors in the regulation of gouty inflammation. Curr Rheumatol Rep. 2011, 13 (2), 138-145.

7. Mittag F., Wuenschel M.: Giant gouty tophi of the hand and wrist. Orthopedics. 2011, 34 (11), e790-792.

8. Kao J.L., Hung J.J., Huang C.H., Shiao C.C.: Giant tophi in the calf. Intern Med. 2012, 51 (3), 335-356.

9. Mavaddat N., Valderas J.M., van der Linde R., Khaw K.T., Kinmonth A.L.: Association self-rated health with multimorbidity, chronic disease and psychosocial factors in a large middle-aged and older cohort from general practice: a cross-sectional study. BMC Fam Pract. 2014, 15 (1), 185-196.

10. Hsu C.C., Chen S.C., Liu C.J., Lu T., Shen C.C., Hu Y.W. et al.: Rheumatoid arthritis and the risk of bipolar disorder: a nationwide population-based study. PLoS One. 2014, 9 (9), e107512. 